Нина Павловић ${ }^{1}$

Универзитет у Нишу,

Филозофски факултет,

Департман за социологију, Ниш, Србија
Прегледни рад

UDK 316.752:2(497.11)“20“"

Примљено: 11.12.2018.

Ревидирана верзија: 21.7.2019.

Одобрено за штампу: 22.7.2019.

DOI: https://doi.org/10.46630/gsoc.22.2019.02

\title{
СПИРИТУАЛНОСТ НОВОГ ДОБА У СРБИЈИ: АНАЛИЗА ПОДАТАКА ЕВРОПСКЕ СТУДИЈЕ ВРЕДНОСТИ
}

Сажетак: У раду су анализиране карактеристике спиритуалности Новог доба у Србији. Дат је приказ појмовног одређења спиритуалности Новог доба у контексту историјског развоја овог феномена. Циљ рада је мерење заступљености спиритуалности Новог доба у Србији и повезаности спиритуалности и религиозности. Анализирани су подаци из Европске студије вредности из 2008. године. Резултати указују на присуство елемената спиритуалности Новог доба у Србији, али у контексту традиционалне религиозности, те су у складу са резултатима претходних студија које указују на повезаност спиритуалности и религиозности у мање секуларизованим земљама, као и на специфичност спиритуалности Новог доба у зависности од културног контекста.

Кључне речи: Ново доба, спиритуалност, религиозност, Србија, Европска студија вредности.

\section{Увод}

Насупрот очекиваном преовладавању рационалистичког погледа на (,рашчарани”) свет и напуштању духовних вредности у корист „објективног” етоса укорењеног у Просветитељству, у савременом друштву долази до јачања спиритуалних покрета са једне стране, као и до деконструкција темеља „чврсте” науке и напуштања метанарација кроз пројект(е) постмодернизма. Напуштање теорије секуларизације у друштвеним наукама праћено је пре свега појачаним интересовањем за две (суштински супротне) појаве: спиритуалности и фундаментализма. Спиритуалност Новог доба (New Age Spirituality) представља контраверзан појам, око чијег дефинисања не постоји општа сагласност; поред тога, упитан је однос спиритуалности са детрадиционализацијом и постматеријализмом, са једне стране и са религиозношћу и традиционализмом са друге стране. Циљ овог рада је мерење заступљености спиритуалности Новог доба у Србији и мерење повезаности спиритуалности и религиозности. У раду су анализирани подаци Европске студије вредности из 2008. године.

\footnotetext{
${ }^{1}$ nina.pavlovic@filfak.ni.ac.rs

${ }^{2}$ Рад је урађен у оквиру пројекта Традиција, модернизација и нащионални идентитет у Србији и на Балкану у процесу европских интеграција (179074), који реализује Центар за социолошка истраживања Филозофског факултета Универзитета у Нишу, а финансира Министарство просвете, науке и технолошког развоја Републике Србије.
} 


\section{Кључне идеје Новог доба}

Спиритуалност Новог доба може се посматрати као спиритуалност живота, која извире из живота самог, насупрот спиритуалности која се ослања на трансцендентни свет из ког се пројектује: теистичкој спиритуалности за живот која се везује за религиозност (Heelas 2008: 25). Једна од представница Новог доба 1982. године пригодно одређује овај феномен као Сегментирану Полицентричну Интегрисану Мрежу (Segmented Polycentric Integrated Network, $S P I N)$ или као СПИН који обухвата већи број СПИН-ова (Chryssides 2007: 10). Према Хиласу, спиритуалност се може схватити „као колекција путања које изражавају (понекад веома различите) варијације на тему личне религиозности" (Heelas 1993: 105). Битна карактеристика спиритуалности је интеграција више елемената, те се једна изолована пракса не би сматрала елементом Новог доба. Ново доба често се назива покретом или религијом, иако се већина аутора слаже да овај феномен није ни религија, ни покрет, бар не у строгом смислу речи; тако Ново доба треба разликовати од нових религијских покрета, који повезују припаднике на основу заједничких веровања, док Ново доба карактерише флуиднија структура и синтеза већег броја (често супротстављених) система веровања (Melton 2007: 78).

Синтагма „покрет Новог доба” утемељена је у ранијој фази историјског развоја Новог доба. „Златни период” Новог доба повезан је са хипи покретом шездесетих и седамдесетих година 20. века, иако се његови почеци могу наћи четири деценије раније у теозофији и још раније у теозофској организацији Кришнамуртија (Jiddu Krishnamurti) из 1911. године (Sutcliffe 2007: 53). Почеци Новог доба могу се ситуирати између два рата, у период светске кризе и егзистенцијалне несигурности; прецизније током тридесетих година 20. века које обележава специфичан контекст и дискурс (Sutcliffe 2007: 54). Осамдесетих година прошлог века истицан је механизам постизања критичне масе људи који би достигли одређени ниво освешћености а затим пренели остатку човечанства спиритуалне идеје започињући Ново доба или Доба Водолије (Melton 2007: $86)$; ова идеја касније се занемарује а промена на глобалном плану постаје могућа спонтана последица индивидуалних делања.

Повезаност са контракултуром хипи покрета ${ }^{3}$ манифестовала се кроз животни стил који карактерише одбацивање друштвених норми (Heelas 1993; Chryssides 2007). Овај облик одбацивања друштва Хилас сматра моделом контракултурног Новог доба, насупрот моделу компатибилности са капитализмом који карактеришу поруке оснаживања појединца који тежи да добије „најбоље из оба света" (Неelas 1993: 107). Могу се разликовати две фазе Новог доба: а) у виду покрета, блиско повезаног са хипи културом, б) након распада хипи пок-

\footnotetext{
${ }^{3}$ У овом периоду присутне су и друге манифестације Новог доба, ван хипи покрета; током шездесетих година 20. века значајна је и заједница „Фајндхорн“, настала као хортикултурни експеримент чији је неочекивано велики успех приписан натприродним бићима (Chryssides 2007: 8).
} 
рета, у виду флексибилније организоване мреже. Упоређујући термин „покрет Новог доба” са термином „свет спиритуалног” који је у употреби у Јапану, Шимазоно (Shimazono 1999) предлаже употребу новог појма којим би биле обухваћене различите варијације овог феномена и унапређене могућности компаративних истраживања - Покрети и култура нове спиритуалности. Проширујући обим појма на културу, ауторка указује на различите облике учествовања у активностима Новог доба, од групних пракси до усмерености на лични развој (Shimazono 1999: 125). Флуидност Новог доба практично онемогућава описивање граница феномена у појавном смислу, али је могуће утврдити кључне идеје које представљају језгро филозофије Новог доба.

Централна тачка спиритуалности Новог доба је личност појединца, сакрализовано сопство обједињено са Универзумом. Позиција пантеистичког монизма претпоставља да су стваралац космоса и створени појединац једно а разлика између Бога и појединца илузија (Lyon 1993: 119). Појединац интуитивно зна и осећа шта је за њега добро, али спољни системи знања и веровања ограничавају сопство друштвеним улогама. Стога је потребно одбацити друштвено наметнута ограничења и устоличити сопство као ауторитет у тумачењу (субјективне) стварности. Централност сопства легитимише перенијализам и холизам Новог доба: појединац као врховни ауторитет бира и комбинује традиције веровања и пракси према сопственим потребама (Aupers, Houtman 2006: 206). На темељу теозофске традиције, Ново доба заступа филозофију перенијализма, по којој су све религије и системи веровања подједнако валидни, јер је реч о обожавању исте космичке силе, на различите начине (Aupers, Houtman 2006: 203). Негирање апсолутног ауторитета било ког система знања испољава сличност са постмодерним схватањима. Изражено је ослањање на верске традиције Истока, пре свега у наглашавању унутрашње просветљености, гносе као знања које примарно извире из искуства и веровања у свеприсутност карме (Lyon 1993: 119). Ново доба укључује спиритуалистички интерпретиран симболизам квантне теорије, теорије вероватноће и бројних психолошких и социолошких теорија - својеврсну „митологију науке” (Нanegraaff 1999: 153). Ова интеграција религијских традиција и „митологије науке” одвија се у контексту карактеристично модернистичког помака од колективног ка еклектичком приватном симболизму (Hanegraaff 1999: 154). „Холистички миље” Новог доба представља повезане самосталне активности које не реферишу на институционални контекст (Heelas 2006: 47). Холизам у Новом добу не представља друштвену већ космолошку категорију, те може бити речи о „холистичком индивидуализму" - наглашавању индивидуалности појединца у контексту уверења да апстрактна сила повезује све људе у свету (Farias, Lalljee 2008: 279).

Парадоксално, иако антропологија Новог доба конципира човека као суштински доброг и повезаног са другима, наглашавање индивидуалности у Новом добу подрива темеље традиционалне друштвености и морала. Са етичког аспекта, ако друштвене вредности и норме немају моћ над појединцем, постојање било каквог моралног компаса зависи искључиво од личног избора. Ново доба запада у солипсизам, изолујући индивидуу затварањем у приватни 
симболички свет (Hanegraaff 1999: 156-157). На друштвеном нивоу, усмереност на искључиво лични развој и затварање појединца у односу на друштвено релевантна питања или учешћа у друштвеним колективима потенцијално води подржавању statusa quo. Како Лакроа примећује, одговорност мисли појединца за добробит целокупне земље и човечанства потенцијално представља нови вид прикривеног тоталитаризма: „Није ли ту реч о оном првенству корисног изреченом у познатом слогану Новог доба: „Мислите позитивно?” Ту позитивну мисао Ново доба представља улепшану, али сасвим је могуће да та позитивност представља негацију саме мисли" (Lakroa 2001: 65). Са друге стране, резултати Хиласовог истраживања из 2000. године показују да велики број припадника Новог доба изједначава спиритуалност са императивом да појединац буде „пристојно и брижно људско биће” (Heelas 2008: 35). Како је суштинска идеја Новог доба побољшање сопства у циљу хуманијег и срећнијег постојања, а изражено наглашавање индивидуалности условљава напуштање колективистичког и јачање индивидуалног морала, последица је наглашена крхкост културног ресурса који је утемељен у индивидуи (Lyon 1993: 123).

\section{Преглед релевантних истраживања}

Фриск (Frisk 2007: 103) класификује квантитативна истраживања Новог доба у три групе: а) испитивање припадника Новог доба; б) истраживања путем посматрања и анализе садржаја; в) истраживања репрезентативна за целокупну популацију. Истраживања из прве две категорије, које ауторка анализира, најчешће су спроведена у Великој Британији, током деведесетих година 20. века, на узорцима од 50 до 1.000 корисника услуга карактеристичних за Ново доба. Ова истраживања показују да су припадници Новог доба чешће жене него мушкарци, већином старости од 30 до 40 година и уз благу превагу високообразованих испитаника. У трећу категорију спадају и национална и интернационална истраживања која се дотичу спиритуалности у оквиру ширих проблемских целина, попут Европске студије вредности (European Values Study) и Светске студије вредности (World Values Study).

Хилас и Вудхедова (Woodhead) спровели су значајно истраживање заступљености пракси Новог доба у граду Кендал, од 2000. до 2002. године. Резултати „пројекта Кендал” указали су на заступљеност спиритуалности, са тенденцијом даљег раста. Критике ове студије истичу непотпуну поткрепљеност квантитативним подацима и податак да скоро половина учесника не придаје спиритуални значај праксама у којима учествује (Voas, Bruce 2007: 43-63). Хилас у одговору на критику подвлачи податке о заступљености спиритуалних веровања: означавање спиритуалности као значајне за испитаника (71\%) и сагласност са тврдњама о постојању животне силе која прожима све што постоји (82,5\%) и о постојању енергије у телима (73\%) (Heelas 2006: 50; Heelas 2007: 65; Heelas 2008: 37). Воас и Брус сматрају да је мањи део учесника посвећен личном расту, а већи део заинтересован само за здравствене ефекте пракси; ова 
критика заправо сумира суштинску разлику између супротстављених погледа на спиритуалност - Хиласово схватање је шире, те „нијансе” у погледу прихватања спиритуалних веровања убраја подједнако у спектар спиритуалности Новог доба, док Воас и Брус заступају строже становиште, које искључује прагматички приступ спиритуалним праксама.

Релевантан увид у социјалну конструкцију спиритуалности Новог доба пружила је квалитативна студија спроведена у пероду од 1999. до 2003. године, у којој је указано на процес социјализације при приступању Новом добу (Houtman, Aupers, 2006). Заинтересованост за Ново доба код већине испитаника јавља се због незадовољства изазваног претераном идентификацијом са захтевима пословне организације. Усвајање садржаја Новог доба одвија се кроз фазе: стварања новог интерпретативног оквира, излагања новим искуствима и легитимизације новог погледа на свет (Aupers, Houtman 2006: 208). Аутори подвргавају критици уверење о испољавању аутентичног сопства кроз пут Новог доба који је исти за све: „На крају крајева, колико аутентични могу бити када су у ствари социјализовани у заједничко наглашавање примарности личне аутентичности?" (Aupers, Houtman 2006: 211). Међутим, овакви механизми социјализације делују у свим сферама друштва, те друштвени карактер једног процеса не одузима нужно аутентичност личног искуства.

Актуелност Новог доба огледа се и у његовој повезаности са променама вредности у савременом друштву. У истраживању спроведеном 1998. у Холандији потврђена је хипотеза Лукмана (Luckmann) и Хиласа (Heelas) о моралној индивидуализацији, насупрот хипотези секуларизације (Houtman, Mascini 1998). Истраживање новијег датума, које је обухватило податке Светске студије вредности од 1988. до 2000. године, указало је на повезаност спиритуалности са детрадиционализацијом, постматеријализмом и сменом кохорти, интерпретирајући Ново доба као феномен модерности (Houtman, Aupers 2007). Испитујући супротну тезу, Флере и Кирбиш (2007), чије је истраживање обухватило узорак из Србије, Босне и Херцеговине, Словеније и Алабаме, проналазе позитивну повезаност између спиритуалности, религиозности и традиционализма. Даље анализе показале су да је повезаност између религиозности и спиритуалности израженија у мање секуларизованим земљама (Houtman et al 2009); другим речима, положај Новог доба у односу на традиционалне појаве условљен је социокултурним контекстом. Како су анализирани индикатори спиритуалних веровања (веровања у узвишеност сопства, енергију универзума и будуће доба спиритуалног раста) блиски религијским уверењима, може се очекивати да би мерење пракси Новог доба пружило комплекснију слику. Ова претпоставка у складу је са резултатима истраживања из 2001. године, који су показали повезаност позитивног смера између религиозности и спиритуалности, на темељу заједничког уверења о постојању трансцедентних феномена духа који се могу достићи кроз молитву или медитацију (Bainbridge 2004). На условљеност Новог доба социокултурним контекстом указује и истраживање о привлачности миленаризма појединцима који не препознају сопствену улогу у друштву (Potrata 2004). Уочене су разлике између промовисања енергије Новог 
доба као „женске” на Западу, а „мушке” у Словенији - где се везује за индивидуализам, асертивност, моћ и самопоуздање, насупрот социјалистичким вредностима сарадње, једнакости и толеранције (Potrata 2004: 371). Заступљеност спиритуалности остаје на ниском нивоу, без обзира на различитост културног контекста: од процене на 0,5\% популације Велике Британије у 1996. години, до процене на 0,4-1\% укупне популације Словеније (Potrata 2004: 366). Низак обухват популације произлази из структуралних карактеристика Новог доба, мреже без механизама мобилизације и организације учесника.

\section{Методологија истраживања}

У циљу мерења заступљености спиритуалности Новог доба у Србији (без Косова и Метохије), анализирани су подаци Европске студије вредности ${ }^{4}$ из 2008. године. Популација обухвата пунолетне грађане Републике Србије, чији је обим процењен на 6063208 лица, на основу пописа становништва из 2002. године (EVS, GESIS 2016). Примењен је троетапни стратификовани узорак од 1512 испитаника. Узорак чини 46,4\% мушкараца и 53,6\% жена. Старост испитаника креће се од 18 до 89 година, а просечна старост испитаника је 45,97 година. Нижи степен образовања има 24,2\% испитаника, средњи степен 54,9\% и виши степен 20,9\% испитаника.

\section{Резултати}

Нешто више од половине испитаника сматра се духовним, односно заинтересованим за свето и натприродно ${ }^{5}$ што укључује 40,3\% донекле заинтересованих и 17,7\% веома заинтересованих. Није пронађена статистички значајна повезаност између спиритуалности и пола испитаника (Крамерово $\mathrm{B}=0,042$, $\mathrm{p}=0,465)$, а повезаност са старосном категоријом (Крамерово $\mathrm{B}=0,079, \mathrm{p}=0,023)$ и нивоом образовања (Крамерово $\mathrm{B}=0,08, \mathrm{p}=0,005)$ веома је слаба, те наведени резултати не пружају довољно информација за издвајање социодемографског

\footnotetext{
${ }^{4}$ Европска студија вредности (European Values Study) спроводи се од 1981. године, уз стално проширење обима, до укључивања 47 земаља у четвртом таласу 2008. године (EVS, GESIS 2018). На темељима ЕВС студије развија се и сродна Светска студија вредности (World Values Study). Подаци и упитник су доступни на: EVS (2016): European Values Study 2008: Integrated Dataset (EVS 2008) https://dbk.gesis.org/dbksearch/sdesc2.asp?no $=4800 \& d b=e \& d o i=10.4232 / 1.12458$ GESIS Data Archive, Cologne. ZA4800 Data file Version 4.0.0, doi:10.4232/1.12458

${ }^{5}$ Питање у упитнику је постављено на следећи начин: „Без обзира да ли се сматрате религиозним или не, колико се сматрате духовним то јест колико сте заинтересовани за свето или натприродно?“ Понуђени одговори: веома заинтересован, донекле заинтересован, не нарочито заинтересован, незаинтересован. Наведену ставку даље у раду називамо самопроценом спиритуалности: термин spirituality из упитника на енглеском језику, преведен је у упитнику термином „духовност“; међутим, како примећује Јовановић (Jovanović 2016: 108), термин „духовност“ упућује на уже, конфесионално одређено значење појма.
} 
профила спиритуалних испитаника. Податак о заступљености спиритуалности код више од половине испитаника упућује на раширеност спиритуалности у Србији; међутим, обједињеност ставова према светом и натприродном у оквиру истог питања захтева даљу анализу. Већина испитаника одбацује алтернативна веровања која су карактеристична за Ново доба: 66\% испитаника не верује у реинкарнацију и $34,2 \%$ не верује у амајлије. Повезаност између самопроцене спиритуалности и самопроцене религиозности је позитивног смера (Крамерово B=0,275, п=0,000); дистрибуција вредности (табела 1) показује да је у категорији религиозних испитаника највише донекле заинтересованих за свето или натприродно $(44,7 \%)$, у категорији нерелигиозних не нарочито заинтересованих $(40,6 \%)$ и у категорији атеиста највише је незаинтересованих (70,3\%). Због недовољне прецизности индикатора којим се мери спиритуалност не може се закључити да ли је у категоријама спиритуалних и религиозних испитаника реч о обједињености или о паралелном постојању религиозности и спиритуалности Новог доба. Дакле, спиритуалним се могу сматрати само категорије нерелигиозних испитаника и убеђених атеиста, које су веома или донекле заинтересовани за свето и натприродно - ова категорија обухвата 27 испитаника, односно 1,93\% узорка. Овако ниска заступљеност у складу је са заступљеношћу у Великој Британији и Словенији.

Табела 1. Самопрочена спиритуалности и религиозности

\begin{tabular}{|c|c|c|c|c|c|}
\hline & \multicolumn{4}{|c|}{ Заинтересованост за свето или натприродно } & \multirow{2}{*}{ - Укупно } \\
\hline & Веома & Донекле & Не нарочито & Незаинтересовани & \\
\hline Религиозни & $\begin{array}{l}256 \\
20,4 \%\end{array}$ & $\begin{array}{l}560 \\
44,7 \%\end{array}$ & $\begin{array}{l}321 \\
25,6 \%\end{array}$ & $\begin{array}{l}117 \\
9,3 \%\end{array}$ & $\begin{array}{l}1254 \\
100 \%\end{array}$ \\
\hline Нерелигиозни & $\begin{array}{l}4 \\
4 \%\end{array}$ & $\begin{array}{l}17 \\
16,8 \%\end{array}$ & $\begin{array}{l}41 \\
40,6 \%\end{array}$ & $\begin{array}{l}39 \\
38,6 \%\end{array}$ & $\begin{array}{l}101 \\
100 \%\end{array}$ \\
\hline Убеђени атеисти & $\begin{array}{l}1 \\
2,7 \%\end{array}$ & $\begin{array}{l}5 \\
13,5 \%\end{array}$ & $\begin{array}{l}5 \\
13,5 \%\end{array}$ & $\begin{array}{l}26 \\
70,3 \%\end{array}$ & $\begin{array}{l}37 \\
100 \%\end{array}$ \\
\hline Укупно & $\begin{array}{l}261 \\
18,8 \%\end{array}$ & $\begin{array}{l}582 \\
41,8 \%\end{array}$ & $\begin{array}{l}367 \\
26,4 \%\end{array}$ & $\begin{array}{l}182 \\
13,1 \%\end{array}$ & $\begin{array}{l}1392 \\
100 \%\end{array}$ \\
\hline
\end{tabular}

Резултати показују повезаност средње јачине између самопроцене спиритуалности испитаника и индикатора религиозности (табела 2): припадања деноминацији, проналажење снаге у цркви, вршење молитве ван обреда и веровања у религијске догме (веровање у бога, рај, пакао, грех), али и између самопроцене спиритуалности и типичних «њу ејџ» веровања и пракси (веровања у реинкарнацију и амајлије и афирмисање сопственог повезивања са божанским). Наведене мере указују на двоструко схватање спиритуалности, са 
обзиром на њену повезаност са индикаторима религиозности али и са индикаторима алтернативних веровања и пракси Новог доба.

\section{Табела 2. Повезаност самопрочене спиритуалности са индикаторима религиозности и спиритуалности Новог доба}

\begin{tabular}{ll}
\hline $\begin{array}{l}\text { Индикатор религиозности/ } \\
\text { спиритуалности Новог доба }\end{array}$ & Крамерово В \\
\hline Припадање деноминацији & $0,248^{* *}$ \\
\hline Веровање у бога & $0,365^{* *}$ \\
\hline Веровање у рај & $0,340^{* *}$ \\
\hline Веровање у пакао & $0,330^{* *}$ \\
\hline Веровање у грех & $0,291^{* *}$ \\
\hline Молитва богу ван религијских обреда & $0,301^{* *}$ \\
\hline Проналажење снаге у цркви & $0,305^{* *}$ \\
\hline Веровање у реинкарнацију & $0,251^{* *}$ \\
\hline Веровање у амајлије & $0,225^{* *}$ \\
\hline Сопствени начин повезивања са божанским & $0,185^{* *}$ \\
\hline
\end{tabular}

** коефицијенти значајни на нивоу сигурности од 99\%

У табели 3 приказана је дистрибуција самопроцене спиритуалности и веровања у истинитост само једне религије; повезаност између варијабли је средње јачине (Крамерово $\mathrm{B}=0,238, \Pi=0,000)$ а у табели се може приметити правилан тренд према коме је придавање већег значаја спиритуалности повезано са прихватањем веровања у истинитост сопствене религије и са одбацивањем других религија $(38,7 \%)$. Нивои највеће заинтересованости за спиритуалност повезани су са одбацивањем истинитости других религија, супротно перенијализму Новог доба, што упућује на тумачење самопроцене спиритуалности у контексту традиционалне религиозности. 
Табела 3. Самопроцена спиритуалности и веровање у истинитост само једне религије

\begin{tabular}{|c|c|c|c|c|c|}
\hline & \multicolumn{5}{|c|}{ Заинтересованост за свето или натприродно } \\
\hline & Веома & Донекле & $\begin{array}{l}\mathrm{He} \\
\text { нарочито }\end{array}$ & Незаинтересовани & Укупно \\
\hline $\begin{array}{l}\text { Само једна истинита } \\
\text { религија }\end{array}$ & $\begin{array}{l}101 \\
38,7 \%\end{array}$ & $\begin{array}{l}147 \\
26,1 \%\end{array}$ & $\begin{array}{l}76 \\
22,4 \%\end{array}$ & $\begin{array}{l}33 \\
20,4 \%\end{array}$ & $\begin{array}{l}357 \\
26,9 \%\end{array}$ \\
\hline $\begin{array}{l}\text { Само једна истинита } \\
\text { религија, } \\
\text { али све садрже } \\
\text { истините елементе }\end{array}$ & $\begin{array}{l}94 \\
36,0 \%\end{array}$ & $\begin{array}{l}237 \\
42,1 \%\end{array}$ & $\begin{array}{l}93 \\
27,4 \%\end{array}$ & $\begin{array}{l}28 \\
17,3 \%\end{array}$ & $\begin{array}{l}452 \\
34,1 \%\end{array}$ \\
\hline $\begin{array}{l}\text { Нема истините } \\
\text { религије, } \\
\text { али све садрже } \\
\text { истините елементе }\end{array}$ & $\begin{array}{l}61 \\
23,4 \%\end{array}$ & $\begin{array}{l}149 \\
26,5 \%\end{array}$ & $\begin{array}{l}121 \\
35,7 \%\end{array}$ & $\begin{array}{l}35 \\
21,6 \%\end{array}$ & $\begin{array}{l}366 \\
27,6 \%\end{array}$ \\
\hline $\begin{array}{l}\text { Ниједна религија } \\
\text { не нуди истину }\end{array}$ & $\begin{array}{l}5 \\
1,9 \% \\
\end{array}$ & $\begin{array}{l}30 \\
5,3 \% \\
\end{array}$ & $\begin{array}{l}49 \\
14,5 \% \\
\end{array}$ & $\begin{array}{l}66 \\
40,7 \% \\
\end{array}$ & $\begin{array}{ll}150 \\
11,3 \% \\
\end{array}$ \\
\hline Укупно & $\begin{array}{l}261 \\
100 \%\end{array}$ & $\begin{array}{l}563 \\
100 \%\end{array}$ & $\begin{array}{l}339 \\
100 \%\end{array}$ & $\begin{array}{l}162 \\
100 \%\end{array}$ & $\begin{array}{l}1325 \\
100 \%\end{array}$ \\
\hline
\end{tabular}

Добијени резултати у складу су са резултатима претходних истраживања који указују на повезаност спиритуалности са религиозношћу и традиционализмом у мање секуларизованим земљама (Flere, Kirbiš 2007; Houtman et al 2009). Анализирајући религију у Србији неопходно је имати у виду специфичност друштвене средине, обележене традиционализацијом, јачањем национализма током балканских сукоба и променом улоге религије након пада социјализма (Gavrilović 2013: 30). Подаци који се односе на религиозност, у складу су са утврђеним трендом ревитализације религије у Србији, која се испољава кроз три димензије: раст броја верника, интензификацију религијске праксе и деприватизацију улоге религије (Gavrilović 2013). Када је реч о схватању природе божанства, 56,7\% испитаника верује у духовну или животну силу, а само $18,3 \%$ у божанску личност. Са друге стране, спиритуалност још увек спада у домен цркве и религије: $62 \%$ испитаника сматра да црква одговара на духовне потребе људи. Већина испитаника изјављује да припада религијској деноминацији $(68,7 \%)$, сматра се религиозном особом $(85,2 \%)$ и придаје значај религијским обредима при рођењу $(81,7 \%)$, браку $(86,6 \%)$ и смрти $(89,6 \%)$. Занимљиво је да већина испитаника не верује у рај $(52,2 \%)$ и пакао $(59,1 \%)$, док у Бога верује $84,9 \%$ и у грех $61,9 \%$. Овакво схватање религиозности је у великој мери једнодимензионално; наглашено је веровање у бога као духовну силу која санкционише грех и афирмише моралност, уз (делимично) одбацивање традиционалних религијских учења. Анализирајући податке Европске студије вредности, Гавриловић закључује да дистрибуција наведених јаких показатеља религиозности указује на присуство верника који „практикују традиционалну, помодну или неку другу врсту религиозности која не подразуме- 
ва интериоризацију основних елемената догме” (Gavrilović 2013: 40). Ауторка издваја два доминантна типа религиозности у Србији, површну традиционалну и еклектичку религиозност, која комбинује посећивање цркве, веровање у црквену догму и сујеверje (Gavrilović 2013: 45). Дакле, ова димензија обухвата и одређене елементе Новог доба у комбинацији са традиционалном религиозношћу. Јовановић закључује да компатибилност православља, као доминантне професије у Србији и спиритуалности проистиче из следећих карактеристика православља: синкретички или еклектички карактер, одсуство јединствене, ригидне и рационалне догме и слабо развијена сазнајна компонента религијске културе (Jovanović 2016: 127-129).

Употреба појма спиритуалности или духовности проблематична је у оквиру анкетног истраживања, где остаје нејасно како испитаник разуме овај термин; тако су 1997. године испитаници из Пенсилваније и Охаја најчешће описивали спиритуалност као личну повезаност са Богом и духовним силама (Zinnbauer et al 1997), док у Великој Британији 1995. године испитаници за спиритуалност најчешће везују појмове универзалне силе, енергије и вибрације, без помена божанства (Rose 1998: 12). Како Гавриловић (Gavrilović 2013: 42 ) истиче, препоручљив је опрез у тумачењу квантитативних анализа религиозности због ограничених могућности ове врсте истраживања за тумачење и разумевање различитих облика религиозности. Наведени проблеми упућују на потребу креирања сензитивнијих индикатора спиритуалности, уз ослањање на резултате квалитативних истраживања.

\section{Закључак}

Ново доба представља контроверзан појам, често пежоративно представљен као израз конзумеризма капиталистичког друштва. Међутим, кроз перенијализам и поштовање јединствености појединца, идеје Новог доба могу допринети толеранцији различитости на друштвеном и личном нивоу, те је реч о феномену чије је проучавање релевантно за науку и друштво. Ново доба упућује изазов друштвеној контроли и кохезији, попут симптома епистемолошке и социјалне кризе (пост)модерности. Претходна истраживања указују на флуидност Новог доба у савременом друштву, која омогућава повезаност са религиозношћу и традиционализмом у неразвијеним друштвима и повезаност са силама модерности у развијеним земљама. Резултати указују на заступљеност спиритуалности у контексту традиционалне религиозности у Србији, међутим, битно је указати на недостатке мерења спиритуалности наведеним индикаторима и на ограниченост домета квантитативних истраживања у проучавању облика религиозности. Спроведена анализа потврђује претходне закључке о специфичном односу Новог доба и сила модерности с обзиром на карактеристике и ниво развоја датог друштва. 


\section{Литература}

Aupers, S., Houtman, D. (2006) „Beyond the Spiritual Supermarket: The Social and Public Significance of New Age Spirituality“, Journal of Contemporary Religion XXI (2): 201-222.

Bainbridge, W. (2004) „After the New age“, Journal for the Scientific Study of Religion XLIII (3): 381-394.

Chryssides, G. D. (2007) „Defining the New Age“ in Handbook of New Age (D. Kemp, J.R. Lewis, eds.), 5-25. Boston: Leiden.

EVS (2016) European Values Study 2008: Integrated Dataset (EVS 2008) https://dbk. gesis.org/dbksearch/sdesc2.asp?no $=4800 \& \mathrm{db}=\mathrm{e} \& \mathrm{doi}=10.4232 / 1.12458$. GESIS Data Archive, Cologne. ZA4800 Data file Version 4.0.0, doi:10.4232/1.12458

EVS, GESIS (2016) EVS 2008 Method Report. GESIS-Technical Reports. Documentation release 2016/12/29.

EVS, GESIS (2018) European Values Study History. https://europeanvaluesstudy.eu/ about-evs/history/ приступљено: 10.12.2018.

Farias, M., Lalljee, M. (2008) "Holistic Individualism in the Age of Aquarius: Measuring Individualism/Collectivism in New Age, Catholic, and Agnostic Groups", Journal for the Scientific Study of Religion XLVII (2): 277-289. DOI: 10.1111/j.14685906.2008.00407.x.

Flere, S., Kirbiš, A. (2007) "New Age, Religiosity, and Traditionalism: A Cross-Cultural Comparison”, Journal for the Scientific Study of Religion XLVIII (1): 161-184.

Frisk, L. (2007) “Quantitative Studies of New Age” in Handbook of New Age (D. Kemp, J.R. Lewis, eds.), 103-123. Boston: Leiden.

Gavrilović, D. (2013) Doba upotrebe: religija i moral u savremenoj Srbiji. Niš: Filozofski fakultet u Nišu.

Hanegraaff, W. J. (1999) “New Age Spiritualities as Secular Religion: a Historian's Perspective", Social Compass XLVI (2): 145-160.

Heelas, P. (1993) „,The New Age in Cultural Context: the Premodern, the Modern and the Postmodern", Religion (23): 103-116.

Heelas, P. (2006) "Challenging Secularization Theory: The Growth of "New Age" Spiritualities of Life", The hedgehog review: critical reflections on contemporary culture: after secularization 8 (1-2): 46-58. University of Virginia: Institute For Advanced Studies in Culture.

Heelas, P. (2007) "The Holistic Milieu and Spirituality: Reflections on Voas and Bruce" in Sociology of Spirituality (K. Flanagan, P. C. Jupp, eds.), 63-81. Burlington: Ashgate.

Heelas, P. (2008) Spiritualities of life: New age romanticism and consumptive capitalism. Oxford: Blackwell.

Houtman, D., Aupers, S. (2007) "The Spiritual Turn and the Decline of Tradition: The Spread of Post-Christian Spirituality in 14 Western Countries, 1981-2000", Journal for the Scientific Study of Religion XLVI (3): 305-320.

Houtman, D., Aupers, S. Heelas, P. (2009) “Christian Religiosity and New Age Spirituality: A Cross-Cultural Comparison”, Journal for the Scientific Study of Religion XLVIII (1): 169-179. 
Houtman, D., Mascini, P. (1998) "Why Do Churches Become Empty, While New Age Grows? Secularization and Religious Change in the Netherlands", Journal for the Scientific Study of Religion XLI (3): 455-473.

Jovanović, M. (2016) Identitet, religioznost, seksualnost: problem identiteta religioznih LGBT osoba u Srbiji. Novi Sad: Mediterran Publishing.

Lakroa, M. (2001) New Age: ideologija novog doba. Beograd: Clio.

Lyon, D. (1993) “A Bit of a Circus: Notes on Postmodernity and New Age”, Religion (23): $117-126$.

Melton, G. J. (2007) "Beyond Millennialism: The New Age Transformed” in Handbook of New Age (D. Kemp, J.R. Lewis, eds.), 77-102. Boston: Leiden.

Potrata, B. (2004) "New Age, Socialism and Other Millenarianisms: Affirming and Struggling with (Post)socialism”, Religion, State \& Society XXXII (4): 365-379.

Redden, G. (2002) “The New Agents Personal transfiguration and radical privatization in New Age self-help”, Journal of Consumer Culture II (1): 33-52.

Rose, S. (1998) "An examination of the new age movement: Who is involved and what constitutes its spirituality", Journal of Contemporary Religion XIII (1): 5-22.

Shimazono, S. (1999)" "New Age Movement" or "New Spirituality Movements and Culture"?", Social Compass XLVI (2): 121-133.

Sutcliffe, S. (2007) "The Origins of 'New Age' Religion Between the Two Wars" in Handbook of New Age (D. Kemp, J.R. Lewis, eds.), 51-77. Boston: Leiden. Chryssides, G. D. (2007) „Defining the New Age“ in Handbook of New Age (D. Kemp, J.R. Lewis, eds.), 5-25. Boston: Leiden.

Voas, D., Bruce, S. (2007) “The Spiritual Revolution: Another False Dawn for the Sacred" in: Sociology of Spirituality (K. Flanagan, P. C. Jupp, eds.), 43-63. Burlington: Ashgate.

Zinnbauer, B. J., Pargament, K. I., Cole, B., Rye, M.S., Butter, E. M., Belavich, T, G., Hipp, K. M., Scott, A. B., Kadar, J. L. (1997) "Religion and Spirituality: Unfuzzying the Fuzzy", Journal for the Scientific Study of Religion XXXVI (4): 549-564.

\section{NEW AGE SPIRITUALITY IN SERBIA: ANALYSIS OF EUROPEAN VALUES STUDY DATA}

Abstract: The paper analyzes the characteristics of the New Age spirituality in Serbia. The article presents the conceptual definition of the spirituality of the New Age in the context of the historical development of this phenomenon. The aim of the paper is to measure the presence of the New Age spirituality in Serbia and the connection between spirituality and traditional religiousness. The data from the European study of values from 2008 were analyzed. The results indicate presence of elements of the New Age spirituality in Serbia, but in the context of traditional religiosity, and are in accordance with the results of previous studies that point to the connection of spirituality and religiosity in less secularized countries, as well as to the specificity of New Age spirituality, depending on the cultural context.

Keywords: New Age, spirituality, religiousness, Serbia, European Values Study. 